\title{
HISTORICISM IN MODERN ETHNIC PROCESSES: METHODOLOGICAL ASPECTS OF RESEARCH
}

\author{
(C) Maxim G. Kuleshin, Pavel G. Nemashkalov, Elena A. Andreeva \\ Stavropol State Pedagogical Institute, Stavropol, Russian Federation \\ paul_2@rambler.ru
}

In the course of cooperation between different countries, high-level institutions and organizations appear, in which the exchange of experience, the development of economic, scientific and technical cooperation, as well as measures to protect the sovereignty and coordination of the most important foreign policy aspirations of states are carried out. The need for cooperation has led to the creation of a wide network of specialized bodies for joint activities of specialists, including scientists. Social scientists from different countries usually cooperate on a bilateral basis. This is not accidental, since there are purely special problems, the solution of which presupposes the joint activity of societies of several countries. Global interaction in various fields of activity is developing before the eyes of all mankind. New traditions are being formed that contribute to the strengthening of ties between countries, of course, many problems arise. Sluggishness, national narrow-mindedness and sometimes an oversight in the development of fundamental forms of cooperation, and sometimes ignorance of interests, hinder the deployment of new progressive initiatives. The formation and interaction of ethnocultural traditions based on multinationality presuppose mutual concessions on the part of all participants. Hence the problem of territorial-spatial ties, that is, the relationship between subethnic, ethnic and super-ethnic in emerging cultural traditions.

Key words: ethnos, culture, personality, ethnic identity, subethnos, ethnic traditions, society.

\section{[М.Г. Кулешин, П.Г. Немашкалов, Е.А. Андреева Историзм в современных этнических процес- cax: методологические аспекты исследования]}

В ходе сотрудничества между различными странами возникают учреждения и организации высокого уровня, в которых осуществляются обмен опытом, разработка экономического, научнотехнического сотрудничества, а также меры по защите суверенитета и согласованию важнейших внешнеполи-тических стремлений государств. Необходимость сотрудничества привела к созданию широкой сети специализированных органов совместной деятельности специалистов, в том числе ученых. Ученые-обществоведы различных стран обычно сотрудничают на двусторонней основе. Это не случайно, так как существуют сугубо специальные проблемы, решение которых предполагает совместную деятельность обществоведов нескольких стран. Перед глазами всего человечества развертывается глобальное взаимодействие в разных областях деятельности. Формируются новые традиции, содействующие укреплению связей между странами, разумеется, возникает и немало проблем. Косность, национальная ограниченность и порой недосмотр в разработке фундаментальных форм сотрудничества, а иногда игнорирование интересов мешают развертыванию новых прогрессивных начинаний. Формирование и взаимодействие этнокультурных традиций на основе многонациональности предполагают взаимные уступки со стороны всех участников. Отсюда вытекает проблема территориально-пространственных связей, то есть соотношения субэтнического, этнического и суперэтнического в возникающих культурных традициях.

Ключевые слова: этнос, культура, личность, этническое самосознание, субэтнос, этнические традиции, общество.

Maxim G. Kuleshin - Ph.D. in History, Associate Professor, Stavropol State Pedagogical Institute, Stavropol, Russian Federation.

Pavel G. Nemashkalov - Ph.D. in History, Associate Professor, Stavropol State Pedagogical Institute, Stavropol, Russian Federation.

Elena A. Andreeva - Assistant Professor, Stavropol State Pedagogical Institute, Stavropol, Russian Federation.

Кулешин Максим Георгиевич - кандидат исторических наук, дочент, Ставропольский государственный педагогический институт, г. Ставрополь, Российская Федерация. 
Немашкалов Павел Григорьевич - кандидат исторических наук, доцент, Ставропольский государственный педагогический институт, г. Ставрополь, Российская Федерация.

Андреева Елена Анатольевна - старший преподаватель, Ставропольский государственный педагогический институт, г. Ставрополь, Российская Федерация.

It has become customary and recognized in ethnographic research that the components of material culture retain ethnic specificity most steadily, and in the modern era of the rapid spread of a more or less unified (or standardized) global urban culture, it is this culture that has the property long-term preservation of historically established traditions, which "are forms of spiritual and practical development of the world, express the value attitude of man to reality" [4, pp. 9-12], "ensure the education of a positive attitude to cultural differences" [2, pp. 7-10]. In certain periods of the history of the development of ethnic culture, events took place or phenomena were formed, to which the historical memory was later oriented. The most important task here is to deepen our understanding of the laws of functioning and development of the fund of culture of ethnic groups, which ensures the regulation of ethnocultural and ethnic processes in society. This presupposes "the need to consider ... the disposition of social structures" [1, pp. 168-177].

Undoubtedly important and especially difficult is the question of the reasons for the stability in the modern international system of traditional components, which are immeasurably expanding with an increase in the level of education and cultural activity of the individual [7, pp. 15-18] in the context of "the formation of a new social reality" [8, pp. 64-68]. Living or experiencing an ethnic history by a person is a complex multidimensional process. In its cognitive form, it is a generalized assimilation of ethnic and world culture. The types, forms of such generalization can be different. The ethnic picture of the world and its linguistic form of existence are a specific type of integrated perception of historical reality.

The peoples within the framework of a common statehood have a great experience of joint activities in all spheres of life. However, cooperation on the scale of modern globalization processes is a new phenomenon for them. In the region of Europe from the Baltic to the Black Sea, there are contiguous states. The nations of this region have their own unique individual face, their centuries-old culture, value orientations determined by national tradition. But along with the traditions inherited from past generations, these urbanized nations have created and are creating, according to Yulian Bromley, the quintessence of the experience of today. Ethnic identity is a component of their cultural fund. Yu. Bromley defines this phenomenon as the self-awareness of members of an ethnic group, as if focusing ideas about the community of territory (native land), language (native language), distinctive features of culture and psyche, as well as community of origin and historical destinies the people included in it. The ethnic uniqueness of the language is largely contained in the system of secondary nomination, i.e. metaphor. It is true that the spirit of the people most deeply expresses itself in metaphors, they most faithfully convey the difference in thinking and feeling of races and tribes. The linguistic picture of the world develops along with the development of the ethnos and is conditioned by this development. Just as there are three main types of ethnic self-awareness - ethnic groups of pre-class societies, ethnic groups of class societies and ethnic groups of the same type in the class relation of societies, one can assume the existence of three types of pictures of the world of ethnic groups.

Considering the stereotype as the consolidation in the consciousness of the representatives of the ethnos or subethnos of the most typical forms of the components of the life support system and as the reproduction of these forms with varying degrees of variability, we can confidently assert that in the named components (in general, they have preserved at least a century historical experience) only stereotyped, variable forms exist in 
our time, and not complete traditional structures. And this is natural. The signs that bear the main burden in typologization become the basis for stereotyped manifestations in the culture of life support.

Currently, with the expansion of the network of mass communication, the opportunities for the exchange of cultural, including ethnocultural information, not only at the personal level, but also at the public (interethnic) one are increasing. The natural desire during interethnic contacts to present the best progressive elements of their national culture is expressed in the widespread use of ethnic indicators.

Depending on the goals and objectives of the creative development of traditionally stereotyped cultural forms, it becomes necessary to refer to their folk origins, historical memory, the depth of which largely depends on the fund of ethnic stereotypes and the forms of their fixation (written, visual-graphic, phono-sound, real).

The reasons for the stabilization, disappearance, revival and creative development of ethnographic realities have not been exhaustively investigated and require further study. Considered some of them, touching on the temporal aspect of stereotyping the experience of the people's activities, are associated with the life support system. The territorial-spatial analysis of this problem also requires attention, that is, the issues of the ratio of ethnic and sub-ethnic in a synchronous-diachronous context.

Comparison of them with modern areas revealed a tendency towards territorial continuity of ethnocultural phenomena (in particular, construction equipment, volumetric-spatial solutions). The most persistent were the aesthetic stereotypes of ideas about the elements of material culture in the sub-ethnic environment. Historical memory in the material sphere at the sub-ethnic level is much stronger and more stable than at the general ethnic level. This is evidenced by the traditional zonal distribution of modern elements and complexes of traditional everyday culture with a tendency to enlargement (decrease in the variability of intrazonal division) and blurring of the boundaries of ethnographic zones. At the same time, at the ethnic level, there is a tendency to transfer the sign functions of the ethnodeterminant to the elements of the subculture.

Analysis of modern material culture in marginal ethno-contact zones does not yet allow us to speak about the emergence and functioning of interethnic complexes.

However, there are tendencies towards a shift in the emphasis of ethnic perception of elements of the culture of one's own and neighboring ethnic groups, as if there were the integration of ethnic and interethnic labeling of objects. It can be assumed that in modern conditions of special activation of socio-cultural communication, in the process of interchange of cultural values, the formation of interethnic transitional zones on the basis of ethno-contact areas is taking place.

Aspects of human activity associated with the production of material components of culture, ideas about them or their perception as ethnic groups-carriers are relevant here. The main thesis is that communicativeness is one of the most important functions of tradition, it presupposes a number of questions, i.e. which of the components of the material culture of nations most staunchly retain their specificity, being ethnic indicators of historical consciousness; how they function in time, what the factors are that stabilize, consolidate and transmit precisely these and no other components of culture, what is the intensity of their historical existence (discreteness, continuity). Hence, the problem of territorial-spatial ties also follows, that is, the ratio of subethnic, ethnic and superethnic in the cultural tradition, in this case in its material components and their functioning.

Elements of traditional preferences, restrictions and prohibitions are just as long in existence (sometimes continuously for several centuries). Many of these prohibitions, based on a confessional basis, are not ethnic, but super-ethnic in nature and are typical of the East Slavic, East Romanesque, Baltic peoples, that is, for large territorial units, uniting several historical and ethnographic regions. Others have been developed over the centu- 
ries in connection with the rational and hygienic requirements of individual geographic and climatic zones and are typical for most European peoples.

The hard-to-see variety of ethnic pictures of the world is the cultural wealth of mankind. Diverse in details, these pictures are united in the essential foundations of human existence. In fact, the ancient layers of the micro-picture representations of peoples reveal significant similarities that unite the spiritual life of ethnic groups.

New traditions are based on old ones. Ethnic traditions are understood as a type of continuity of group experience, a type of stable phenomena of social life, the transmission of which is the domain of social consciousness. Favorable forms of interethnic communication are the most essential for the quintessence of the experience of our time inherited from the past. In areas of neighboring states, where different nationalities lived, mixed marriages, bilingualism became common, labor collectives consisting of people of different nations, multi-ethnic political and public organizations arose.

Historical ethnographic communities, interethnic elements and integral complexes of multiethnic culture have been formed for a long time. Many components of this culture are closely related to the development of productive forces and socio-economic changes. However, at a certain stage, they can also become indicators of ideas about an ethnos (subethnos) among the natives themselves and their environment. Certain elements of culture are predetermined by various factors: environmental, socio-economic, prestige, but the stereotype of ideas about them fixed in the mind often persists much longer than these realities themselves, which are associated with "public consciousness ... common cultural norms and values" [6, pp. 6-12].

With the tendency to reduce the ethnically specific in the life of the peoples, their national identity is growing. This is explained by the fact that the objective basis for the formation of national identity is not limited to traditional, ethnically specific culture. It also includes modern culture, including professional culture, which is actively developing among peoples. In addition, the formation of national self-consciousness is based on the reflection in the minds of people of such objective phenomena as the presence of each nation of its own historical past, the territory of settlement, finally, all socio-economic, political, cultural factors around which national interests are concentrated. The growth of national selfawareness objectively depends on the level of socio-economic and cultural development of peoples, the outlook of people, the expansion of their spheres of life, interethnic contacts (direct and mediated). Formed and grown national self-consciousness is among modern peoples, as it were, part of their spiritual arsenal.

It may not be actualized, potential, but it may become more active under certain social, political conditions. The positive or negative meaning of such activity depends, first of all, on the goals towards which the actions of people are directed. In the case of concentration of national interests on egocentric goals, the actualized national self-awareness can isolate peoples, lead to manifestations of parochialism and national isolation, and complicate international relations. But we must not forget that active national self-awareness, awareness of historical responsibility before their people, pride in them with the direct social interest of people in the success of their activities enhance their social and public enthusiasm, can serve the social progress of the nation and all the people.

Some elements of culture are particularly persistent, and even if they cease to exist for some time, then later they begin to exist again actively. The discreteness of these elements does not diminish their importance as a social phenomenon; on the contrary, it is they that often occupy a prominent place in the system of traditions. They were formed in different historical periods of the development of society [3, p. 45-49].

In connection with the emergence and growth of social relations in the process of the development of post-industrial society, ethnic traditions are transformed. 
In the second half of the $19^{\text {th }}$ - early $20^{\text {th }}$ centuries, the traditions inherited from the Middle Ages were alive. In accordance with them, peoples of different nationalities, who had just mastered their profession, had to travel to different countries, get hired there and thus improve their professional skills. Such professional practice made it possible to get acquainted with the way of life, working conditions, customs, national specifics of people living in different regions of the country.

With the emergence of a post-industrial society, along with the age-old traditions of living together and cultural interaction, new ethnic traditions appeared, aimed at mutual understanding, cultural and political communication. Old traditions, value norms in interethnic relations were enriched with new norms. These traditions define public consciousness. They are aimed at respecting national traditions, contribute to the establishment of ties between peoples, have ethnically specific forms, and take into account ethnically specific forms of interethnic ties.

In modern conditions, the processes of ethnocultural interaction are clearly manifested. This is a kind of basis upon which one can analyze and then predict the processes of interethnic interactions. Cultural characteristics play an important role here, i.e. language, customs, religion, etc. T.P. Matyash and E.E. Nesmeyanov note "the influence of Orthodoxy on the formation and formation of Russian culture" [9, pp. 39-44].

At the same time, a complete and objective knowledge of the culture, traditions and everyday characteristics of the peoples living in these territories is necessary, it presupposes the cooperation of many branches of social science. A great responsibility lies with sociology, philosophy, and ethnography. Theories that have arisen in ethnographic science have always had a great influence on the mutual perception of peoples. Negative or positive ideas and stereotypes have influenced and continue to influence interethnic contacts. Each nation has developed positive and negative historical images for generations. In the creation of these images, education, literature, social studies, art, and the media play an important role. Historical ideals and images that have arisen as a result of cultural activity become part of the ethnocultural tradition and largely affect the value orientation of the representatives of a given nation. Public perception of good and bad occurs by comparing contemporary events or figures with ideals taken from national history. Moreover, they often approach current international events from the standpoint of idealizing national history. Public consciousness, like the consciousness of an individual, in determining its attitude to a modern event, can proceed only from its own experience, more precisely, from what seems to generations to be the truth proven by experience. And only a few people think about whether the experience of past generations adequately conveys the essence of past events and their main characters.

In the turmoil of the history of any nation, there are common grounds between nations. It happens that in the historical tradition of two or more peoples, one and the same experience will be idealized for one, while the other will have a reasonably critical attitude towards it. In such cases, it is especially important to observe the unwritten code of respect for the traditions of another people. The experience inherited from the past was formed in contradictory conditions. As you know, progress is a historical category associated with a certain formation. True, progressive historical phenomena also have an interformational face, the ethnocultural tradition as a whole and its elements overstep the boundaries of the socio-economic formation. In the context of the modern globalizing social development of nations, the historical experience based on some phenomenon of the history of one people can have an undesirable influence on the course of modern history. So, for example, the bourgeois-democratic revolutions and movements of the middle of the 19th century, which for some peoples coincided with the national liberation wars, had various forms and contexts opposing the peoples, which now, realizing the historical necessity, are developing joint activities in all spheres. 
The new relations between states and peoples are based on the public consciousness of wide circles of the population.

Scientific analysis leads to a reasonable conclusion about the need to get rid of misunderstandings, old grievances and experiences that interfere with new and progressive beginnings.

The real difficulty lies in the fact that the ethnocultural tradition is determined precisely by the fact that its domain - the public consciousness as a whole - organizes all the social units. In the depths of public consciousness, scientific arguments do not act immediately, the elimination of stereotypes inadequate to reality can be carried out only with great tact and sensitivity.

Objective and complete information about the culture, traditions and life of ethnic communities is an important tool for the formation of a new type of public consciousness.

\section{Лumepamypa}

1. Бакланова О.А. Бакланов И.С. Современная российская социальность в контексте социального конструкционизма // Вопросы социальной теории. 2015. Т. 7. № 1-2. C. $168-177$.

2. Говердовская E.B. Особенности проектирования образовательного пространства высшей школы в поликультурном регионе // Экономические и гуманитарные исследования регионов. 2014. №4. С. 7-10.

3. Гончаров В.Н. Социальный аспект религии в контексте развития первобытного общества // Гуманитарные и социально-экономические науки. 2016. №2(87). С. 45-49.

4. Ерохин А.М. Религия и искусство в системе культуры // European Social Science Journal. 2014. № 7-2 (46). C. 9-12.

5. Карташев А.В., Спевак Р.С., Склярова Е.К., Камалова О.Н. Становление высшего медицинского образования на Северном Кавказе (1915-1945). Учебное пособие / под ред. В.И. Кошель. Ставрополь, 2018.

6. Колосова О.Ю. Духовная сфрера: универсализм и самобытность // European Social Science Journal. 2012. №11-2(27). C. 6-12.

7. Лобейко Ю.А. Социально-педагогический аспект активности личности в системе общественного развития // Экономические и гуманитарные исследования регионов. 2015. №1. С. 15-18.

8. Лукьянов Г.И. Трансформационные процессы в современном российском обществе как отражение динамики новой социальной реальности // Экономические и гуманитарные исследования регионов. 2017. №4. С. 64-68.

9. Матяш Т.П., Несмеянов Е.Е. Православный тип культуры: идея и реальность // Гуманитарные и социально-экономические науки. 2015. № 3 (82). С. 39-44.

10. Матяш Т.П., Матяш Д.В., Несмеянов Е.Е. "Науки о природе" и "науки о духе": судьба старой дилеммы // Гуманитарные и социально-экономические науки. 2015. № 1 (80). C. 10-16.

11.Ten Yu.P., Kamalov A.V. Meaning and role of the factor of ethnocultural identification on the behaviour of the consumers in international business // Научный альманах стран Причерноморья. 2015. No 3.

\section{References}

1. Baklanova O.A. Baklanov I.S. Sovremennaya rossiyskaya sotsialnost v kontekste sotsialnogo konstruktsionizma. Voprosy sotsial'noy teorii. [Modern Russian sociality in 
the context of social constructionism. Questions of social theory.]. 2015. V. 7. No. 1-2. pp. 168-177 (In Russian).

2. Goverdovskaya E. V. Osobennosti proyektirovaniya obrazovatelnogo prostranstva vysshey shkoly $v$ polikulturnom regione. Ekonomicheskiye i gumanitarnyye issledovaniya regionov. [Features of designing the educational space of higher education in a multicultural region. Economic and humanitarian studies of the regions]. 2014. No. 4. pp. 7-10 (In Russian).

3. Goncharov V.N. Sotsialnyy aspekt religii v kontekste razvitiya pervobytnogo obshchestva. Gumanitarnyye i sotsialno-ekonomicheskiye nauki. [The social aspect of religion in the context of the development of primitive society. Humanitarian and socio-economic sciences. 2016. No. 2 (87). pp. 45-49 (In Russian).

4. Erokhin A.M. Religiya i iskusstvo v sisteme kultury. [Religion and art in the cultural system]. European Social Science Journal. 2014. No. 7-2 (46). pp. 9-12. (In Russian).

5. Kartashev A.V., Spevak R.S., Sklyarova E.K., Kamalova O.N. Stanovleniye vysshego meditsinskogo obrazovaniya na Severnom Kavkaze (1915-1945). Uchebnoye posobiye [Formation of higher medical education in the North Caucasus (1915-1945). Tutorial]. Stavropol, 2018 (In Russian).

6. Kolosova O.Yu. Dukhovnaya sfera: universalizm i samobytnost [The spiritual sphere: universalism and identity]. European Social Science Journal. 2012. No. 11-2 (27). pp. 6-12 (In Russian).

7. Lobeiko Yu.A. Sotsialno-pedagogicheskiy aspekt aktivnosti lichnosti v sisteme obshchestvennogo razvitiya. Ekonomicheskiye i gumanitarnyye issledovaniya regionov. [Socio-pedagogical aspect of personality activity in the system of social development. Economic and humanitarian studies of regions]. 2015. No. 1. pp. 15-18. (In Russian).

8. Lukyanov G.I. Transformatsionnyye protsessy $v$ sovremennom rossiyskom obshchestve kak otrazheniye dinamiki novoy sotsialnoy realnosti. Ekonomicheskiye i gumanitarnyye issledovaniya regionov [Transformational processes in modern Russian society as a reflection of the dynamics of a new social reality. Economic and humanitarian studies of regions]. 2017. No. 4. pp. 64-68. (In Russian).

9. Matyash T.P., Nesmeyanov E.E. Pravoslavnyy tip kultury: ideya i realnost. Gumanitarnyye i sotsialno-ekonomicheskiye nauki [Orthodox type of culture: idea and reality. Humanitarian and socio-economic sciences]. 2015. No. 3 (82). pp. 39-44. (In Russian).

10. Matyash T.P., Matyash D.V., Nesmeyanov Ye.Ye. "Nauki o prirode" i "nauki o dukhe": sud'ba staroy dilemmy ["Science of nature" and "science of the spirit": the fate of the old dilemma]. The Humanities and Social-Economic Sciences. 2015. No. 1 (80). pp. 10-16 (In Russian).

11. Ten Yu.P., Kamalov A.V. Meaning and role of the factor of ethnocultural identification on the behaviour of the consumers in international business. Science Almanac of Black Sea Region Countries. 2015. No. 3. 